\title{
Vocal Variability of Chaffinch Song (Fringilla coelebs L.) as a Condition of Cultural Evolution in Local Populations
}

\author{
Olesya Anatolyevna Astakhova \\ Department of Vertebrate Zoology, Faculty of Biology, Moscow State University of M. V. Lomonosov, Moscow, \\ Russia \\ Email: chaffinch@bk.ru
}

Received 27 January 2014; revised 4 March 2014; accepted 12 March 2014

Copyright (C) 2014 by author and Scientific Research Publishing Inc.

This work is licensed under the Creative Commons Attribution International License (CC BY). http://creativecommons.org/licenses/by/4.0/

(c) (i) Open Access

\section{Abstract}

There are such characteristics of a matter of the nature, as variability and stability (tradition, norm). Probably, these opposites process as if other qualities of different forms of energy also create "movement" development. Thus the given properties of a matter of the nature can be considered at different levels of its organization. The singing of many passerine birds is incontrovertible feature of their life which determines and builds a reproductive cycle. By studying song repertoire of many sparrow species in details, it was revealed that the individual has not only one, but some types of songs. Thus spring singing represents the multifunctional phenomenon and can bear (carry) various values. The singing is not only a means of attracting females, but also a means of intimidation of the contender and delimitation of nested territory. Variants or types of species-specific song are individually various and distributed between individuals of a population. The complex interrelation of geographical variability of chaffinch song in many respects gives a support at an evolutionary view in the given aspect.

\section{Keywords}

Species-Specific Song of Chaffinch; Different Song Types; Song Cultures; Song Evolution

\section{Introduction}

In early works, song geographical variability of many species of birds was marked as a phenomenon of differentiation song structures or song patterns (as the image on sonograms) in different localw populations [1]-[4]. Local variants of bird vocalizations can be considered as an analogy of human speech and to name dialects. The 
word "dialect" has taken place from linguists and means a local speech variant, characteristic for the region. Borders of a dialect define lexical (dictionary structure), morphological (an accent, structure) and phonetic (pronunciation) the characteristic of the dictionary [5].

Explanation of bird song variability shows that traditional patterns of vocal behavior do not exist equally with morphological features (more likely, as separate aspect). It is partly due to the result of cultural evolution of birds which represents the important factor, as though a traditional heredity developed, but, apparently, it's not a parameter in morphological variability [6]-[8].

The basic (base, the basic) structure of bird vocalization represents fundamental, stabilized, species specific characteristic features of vocalization [9]. Many local populations of bird are characterized by the populationspecific image (on sonograms) a vocal pattern (dialect). Dialects of birds can be defined as vocal variants with mosaic distribution [10] [11]. This mosaic definition is one of the basics which are widely used, but the majority of microgeographical variability of bird song researchers are not precisely enough asserted (approved) in studying vocal distribution, whether there is a mosaic pattern [12] [13].

Chaffinch (Fringilla coelebs L.) is a classical object of studying of becoming of vocal repertoire [14]-[16] and of geographical variability species specific songs in a population [17]-[19]. As against many others, chaffinch (Fringilla coelebs L.) has harmonious, frequently short, precisely organized and greater degree song genetically determined in a time and frequency range [20]. The size of song repertoire of one chaffinch individual is within the limits of 1 - 6 (10) types of songs [21].

Regional variability of bird song can be determined in qualitative aspects (the form of a syllable, syntax) and quantitative (time-and-frequency) parameters. The concept of a dialect should be closely (cautiously) and carefully argued in an establishment of the regional variability signal and song patterns of birds.

These studies indicate the process of cultural evolution of birds at the example of the chaffinch. Cultural (vocal) evolution of birds has long been detected, but as it happens in birds with different species-specific types, song is shown more clearly.

\section{Material and Methods}

One of problems of our researches has consisted in revealing macrogeographical distinctions of chaffinch song (Fringilla coelebs L.) in different local populations which are removed approximately on $1000 \mathrm{~km}$ from each other. In northwest (Curonian spit, Kaliningrad region) and central parts of the European Russia (Zvenigorod, Moscow, Michurinsk) have been made tape recorder records of singing males during the spring-and-summer period of 2005-2006 ( $\mathrm{N}=218$ males). For record of songs used tape recorder Panasonic RQ-SX95F, condenser microphone Philips SBC ME570.

Sonograms of song type were analyzed with the help of computer program Avisoft SASLab Light. In total it is analyzed about five thousand songs. To one type considered the songs, having two or all three similar parts: started singing (the row of whistle elements), trill elements, a final stroke (they as can be subdivided into phrases - the elements similar in the form). Types of songs were marked by Latin letters.

At the analysis of song sonograms basically applied two qualitative methods: revealing of phonetic distinctions (frequency of a sound, its form on sonogram) or ways of a pronunciation of syllables of the phrases making songs; revealing of lexical distinctions (changes of phrases of songs, as a whole) [22].

As the quantitative analysis of dialect song forms of one type and comparison of their basic time-and-frequency parameters (duration of all songs, number of elements in song type, duration of syllables in a trill, the maximal, minimal and average (median) frequency of songs, intervals between songs) was carried out (was spent).

Chaffinch inhabits at the forests and areas, where there are trees, bushes (parks, gardens). Chaffinch is migrant on average distances, during the winter it flies away to the South (from the Curonian spit at Kaliningrad region to the South of Europe, from the European part of Russia to the Caucasus, Kazakhstan).

Chaffinch (Fringilla coelebs L.) on Zoological classification belongs to the order Passeriformes (Sparrows), to the family Finches (Fringilidae) (the family of birds also include the goldfinch, bullfinch), to the genus Finches (Fringilla) (the genus of birds also include a Brambling). The chaffinch species distribution on area (habitat) very large — occupied Europe, parts of North Africa, the Canary Islands, a part of Asia, European Russia, a part of Siberia, and it has 13 subspecies. In size as a sparrow. Male have grey-dark blue top of a head, a back is chestnut, a forehead is black, the bottom party (side) of a body is red-brown. Wings and a tail are black-brown, 
strips on each side of a tail and on shoulders are white. Female is brown-grey. The nest builds on a tree. In a laying of $4-7$ bluish-green eggs with specks and strips. White strips on wings (a characteristic attribute) are well visible. At many species of sparrow (Passeriformes) males have repertoires from two and more variants of species-specific song.

\section{Results and Discussion}

\subsection{Dialect Song Forms of One Type}

Methods of geographical dialects can be applied to songs of birds. For example, sonograms can be used for definition of vocal variants which are geographically distributed.

Song dialect of birds is a variant of the traditional song form, divided (shared) by the members of a local population of birds and forming borders of a dialect (separating from other variant of song pattern) within the limits of which there is a traditional training (learning) of song components, characteristic the given population. But thus big song repertoires of some sparrow species interfere with objective definition of dialect borders [23]-[25].

In populations of the central part of the European Russia ( $\mathrm{N}=65$ males) we allocate (distinguish) 15 types of chaffinch songs (Fringilla coelebs L.), which were completely similar in structure or are in part modified in the syllabic form (on sonograms) in comparison with songs of corresponding types in samples of a northwest part of the European Russia ( $\mathrm{N}=153$ males). For seven types of songs from twenty two (from sample on Curonian spit) analogies has not come to light-probably, owing to their rarity. Many song types in the central part of the European Russia were considered as combined of phrases of syllabic patterns known to us, but frequently with the changed figure on sonogram.

In result, 12 dialect song forms of one type, which appeared similar in base structure of elements, phrases have been found, but in different regions of Russia frequently had distinguished manners, ways of their performance at singing (phonetic aspect).

The average size of chaffinch repertoire (Fringilla coelebs L.) in populations of the central part of the European Russia from statistical calculations has been submitted $1.93 \pm 0.22$ types of songs (max- 4 types of songs, min -1 song type) at a record on the average $24.7 \pm 11.3$ songs from one male.

As a bright example of chaffinch vocal variability (Fringilla coelebs L.) it is possible to show some local variants of songs which we have attributed to one type (Figures 1, 2). Samples of song types which will be resulted were not single in a population and more than 1-2 individuals have been recorded in repertoires.

In Zvenigorod (Figure 1(b)) started singing (the row of whistle elements) of songs such as type $\mathrm{V}$ has shorter second subelements which are in top concerning the first subelements. Elements of a trill are more complex (difficult) in Zvenigorod (Figure 1(b)). A final stroke-three large base elements are present as at samples of northwest, and the center of the European Russia. But in songs on Curonian spit (Figure 1(a)) before last element $(7)$ of stroke are three small elements $(4,5,6)$ higher frequency $(\mathrm{KHz})$. Probably, it is phonetic components of a dialect, which characterize style of singing (song culture) in a local population on the given type of songs.

(a)
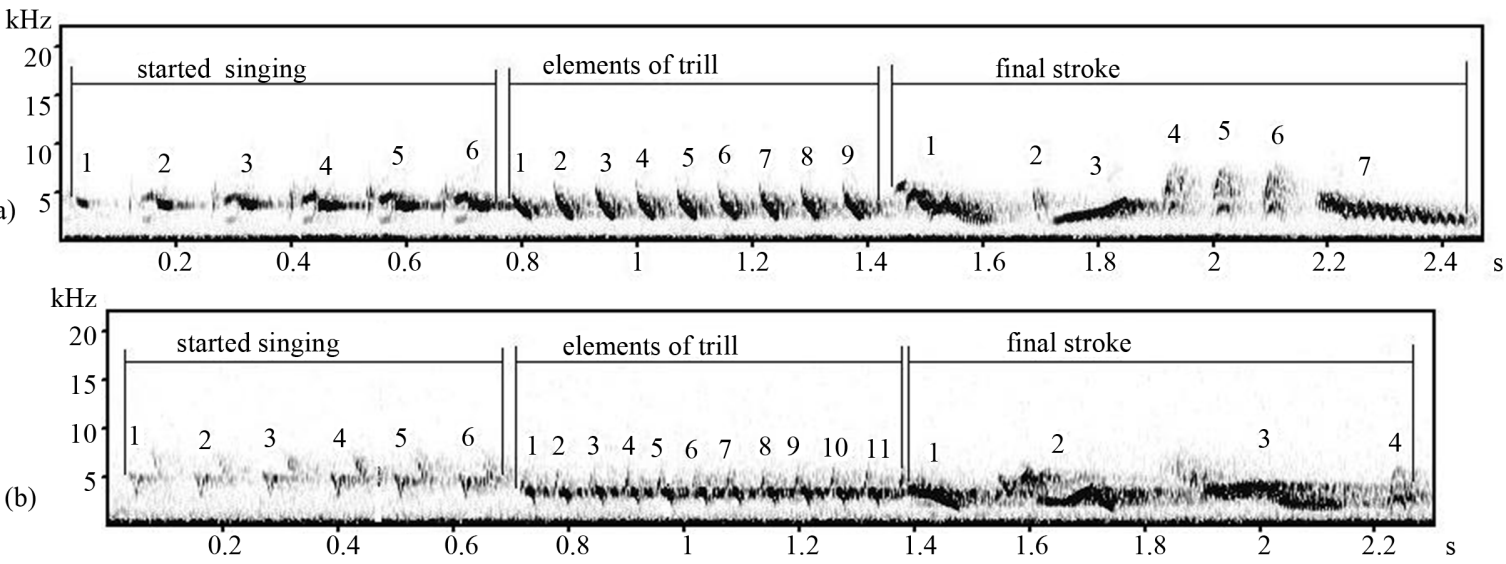

Figure 1. Dialect forms of song types V: (a) Song type V (record on Curonian spit, the Kaliningrad region), (b) Song type V1 (record in Zvenigorod, the Moscow region). 
(a)
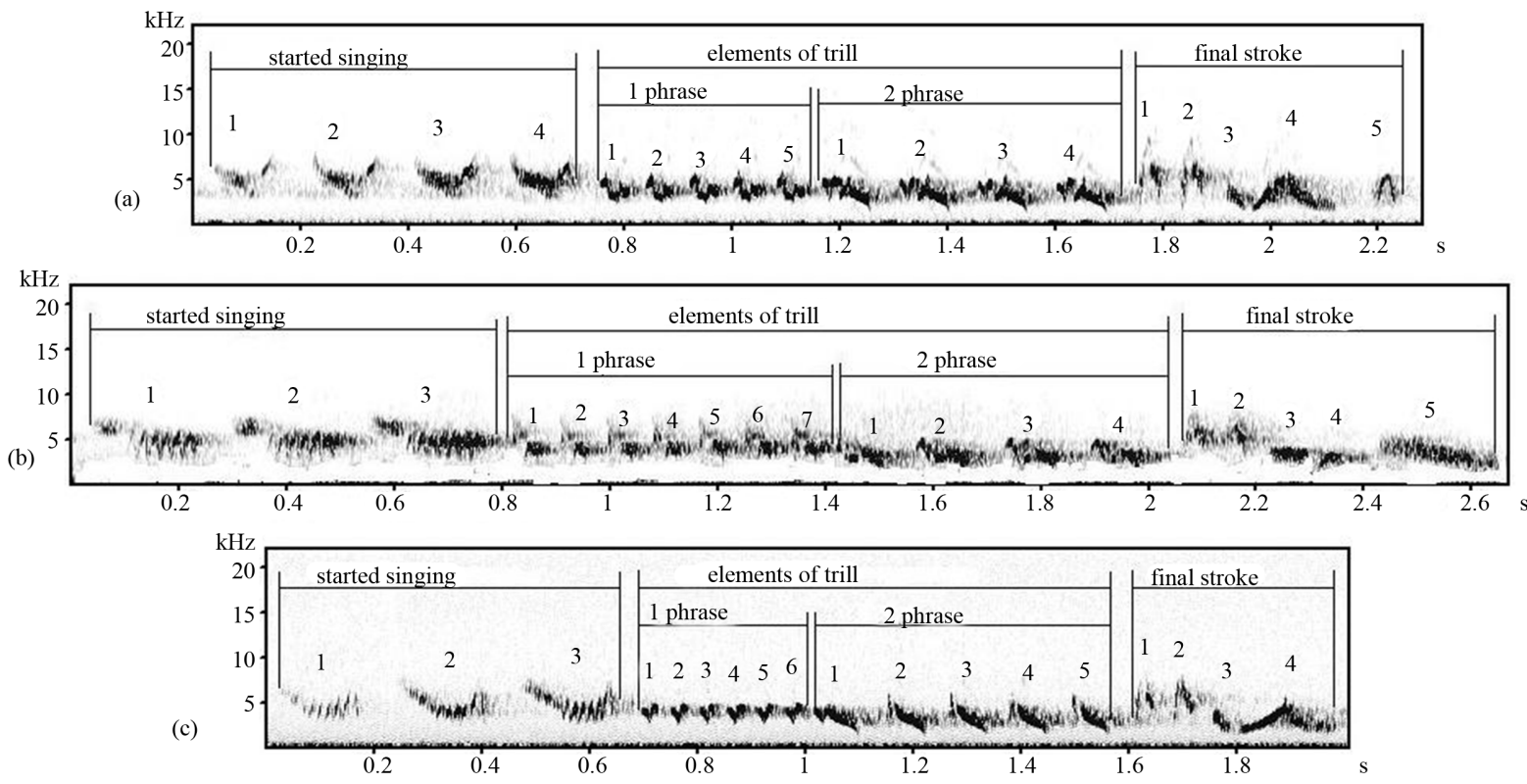

Figure 2. Local variants of song types C (are recorded in different areas of Russia): (a) Song type C (record on Curonian spit), (b) Song type $C^{*}$ (record in Moscow), (c) Song type $C^{*}$ (record on Curonian spit).

Song type C (Figure 2) - the most widespread in all areas of the European Russia investigated by us. Probably, therefore the given song type has some forms on a manner of performance of phrases at singing: simple song type C (Figure 2(a)) and song type $C^{*}$ (Figure 2(c)), recorded on Curonian spit; the song type $C^{\#}$ (Figure 2(b)) is recorded in Moscow. Nevertheless, all these variants of songs on hearing are perceived is similar: started singing - a number (line) sharp (sometimes creaking) of whistle sounds ("fuit-fuit-fuit"), two-phrase trill—the first phrase is heard as a number (line) of more thin sounds, the second phrase-tone of a trill is more powerful ("til-til-til" tel-tel”), a final stroke-short sharp rise and recession of a sound ("chi-kuik").

Whether it is possible these three forms of song type $C\left(C, C^{*}, C^{\#}\right)$ to count dialect even if they meet in one territory (for example, C (Figure 2(a)) and $\mathrm{C}^{*}$ (Figure 2(c)), recorded on Curonian spit)-a question complex (difficult). What origin of these variations of songs of one type-by wrong learning and their further fastening in a population training (song learning) of the following generations, or is result of "introduction" songs of migrants in local song culture-also it is possible to assume only.

In samples song types which are difficult for differentiating among themselves, because of their similarity (Figure 3) have been found. We have attributed the given samples of songs to different types (D, F, G), but nevertheless they are similar among themselves in base structure of elements (especially in started singing and trill), which nevertheless are performance at singing by different manners, ways that does (makes) their distinct. Probably, it is the initial forms of the further modification being in themselves insignificantly transformed for precise revealing of type to which are attributed.

Thus, dialect forms of chaffinch song types (Fringilla coelebs L.) could meet within the limits of one local population in the same territory. Probably, it is result of constant mixing of vocal traditions at migrations [26] [27].

\subsection{Variability of Phrases (Motifs) of Song Types (Lexical Variability)}

According to methods of the qualitative analysis of song types, we had been allocated two basic kinds of their distinctions: lexical and phonetic. Lexical variability of chaffinch song types (Fringilla coelebs L.) will consist in distinction of dictionary structure, phrases of song types.

In variants of song type A (Figure 4), recorded in different points of territory Curonian spit (area of biological research station "Fringilla"), characteristic for these song types the kind of a final stroke is replaced with other, usually making song type C (Figure 2(a)).

Song type W (Figure 5(b)) (it is recorded in Zvenigorod, the Moscow region) it is possible to consider as a 

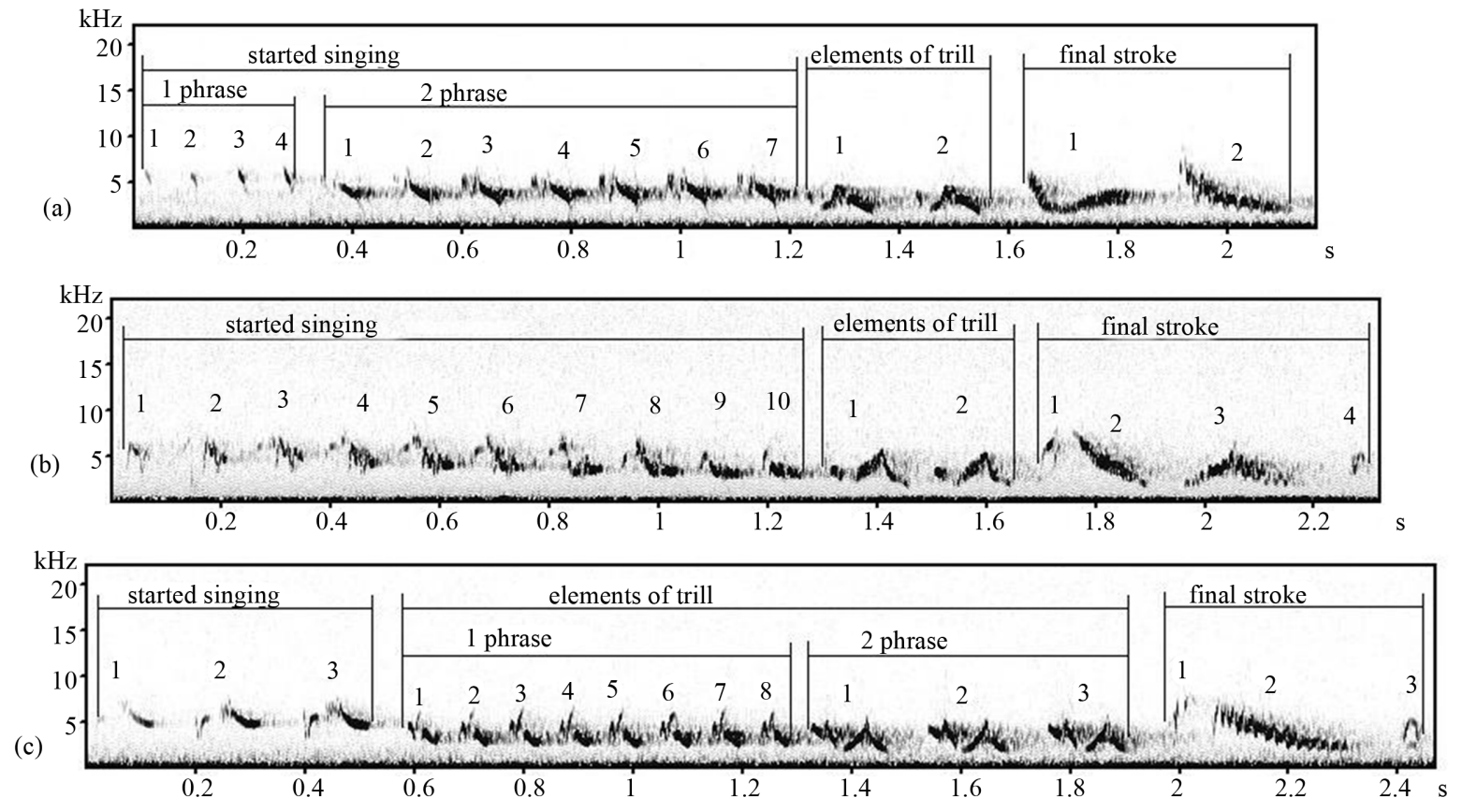

Figure 3. Difficultly differing types of songs of chaffinch (record on Curonian spit, the Kaliningrad region): (a) Song type D, (b) Song type F, (c) Song type G.

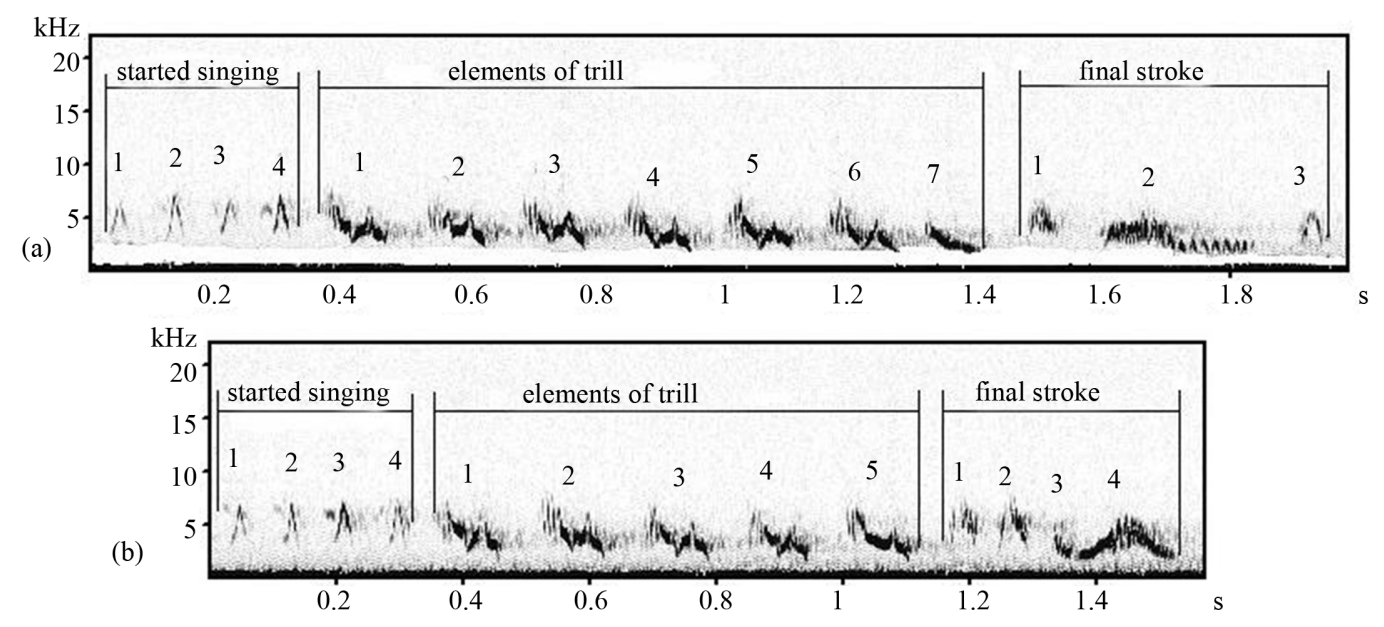

Figure 4. The songs of one type, distinguished by strokes (record on Curonian spit): (a) Song type A, (b) Song type $A^{*}$.

combination of phrases of song types found on Curonian spit: started singing (the row of whistle elements) from song type B (Figure 5(a)) (1-st phrase), a final stroke-from song type H (Figure 5(c)) (last phrase).

Trill elements of song type W (Figure 5(b)) under the form are similar to those of song type B (2-nd phrase of a trill), but finer on the size. Probably, the trill of song types W (Figure 5(b)) and B (Figure 5(a)) is dialect.

In repertoires of the some males there were the "combined" songs consisting of phrases of other song types (Figures 6, 7). Similar cases are described from experiments of song training (learning), when caught young chaffinch male (Fringilla coelebs L.) in first year of his life, in sensitive period, daily played different songs of two wild males. In the result, after a while the caught bird sang a song uniting phrases of songs two wild males [28]. Probably, and us the marked cases are the certificate of non-standard learning of song types during their crystallization.

The song type EI (Figure 6(c)) includes phrases of song type E (Figure 6(a)) and song type I (Figure 6(b)). 
(a)
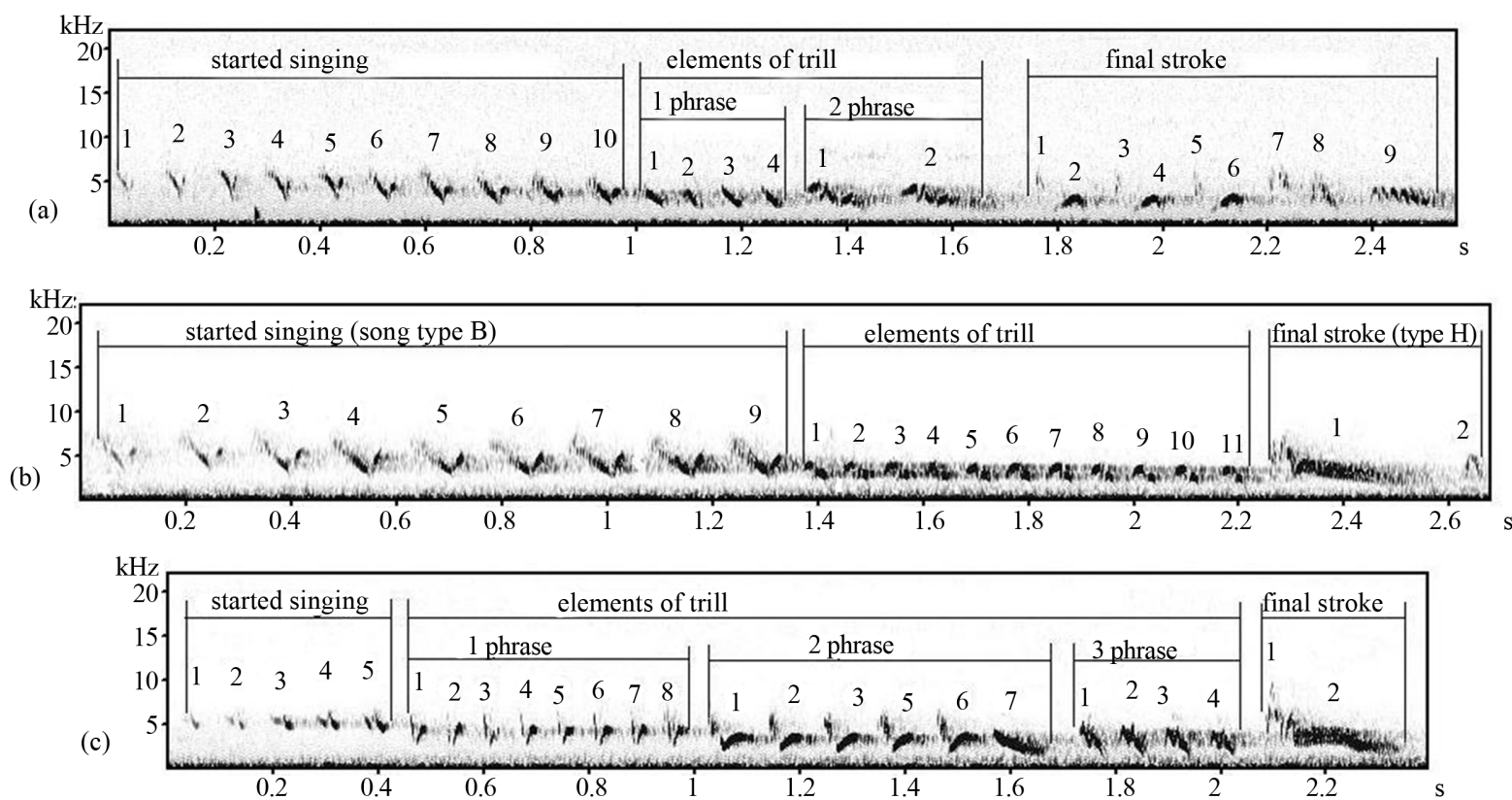

Figure 5. A combination of phrases of song types B and H: (a) Song type B (record on Curonian spit), (b) Song type W (record in Zvenigorod, the Moscow region), (c) Song type H (record on Curonian spit).
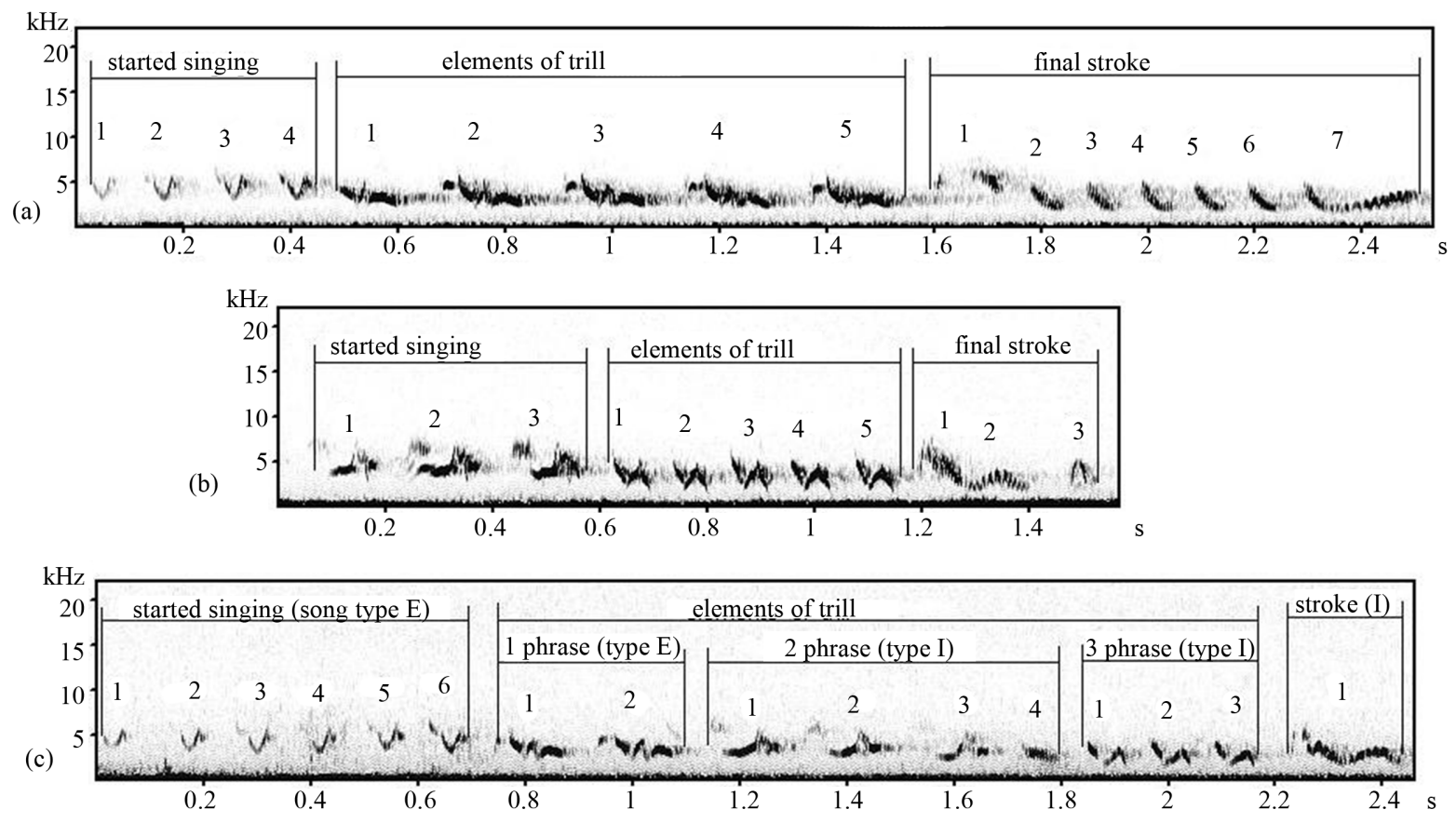

Figure 6. Sonogram of the combined song type of chaffinch (Fringilla coelebs L.), recorded on Curonian spit (those types of songs of which phrases will consist also are shown): (a) Song type E, (b) Song type I, (c) Song type E I.

The song type $\mathrm{OC}^{*}$ (Figure $7(\mathrm{c})$ ) will consist of phrases of song type O (Figure 7(a)) and song type $\mathrm{C}^{*}$ (Figure 7(b)). All these samples of chaffinch songs (Fringilla coelebs L.) have been recorded in population of Curonian spit (both in repertoire of one individual, and at singing of different males).

Such phenomena of lexical distinction of songs of one type within the limits of the certain population of some species of sparrow, bioacoustics explained many from the point of view of natural variations in repertoire of the birds based on vocal generalization and an individualization. The phenomena giving development songs (deve- 
(a)
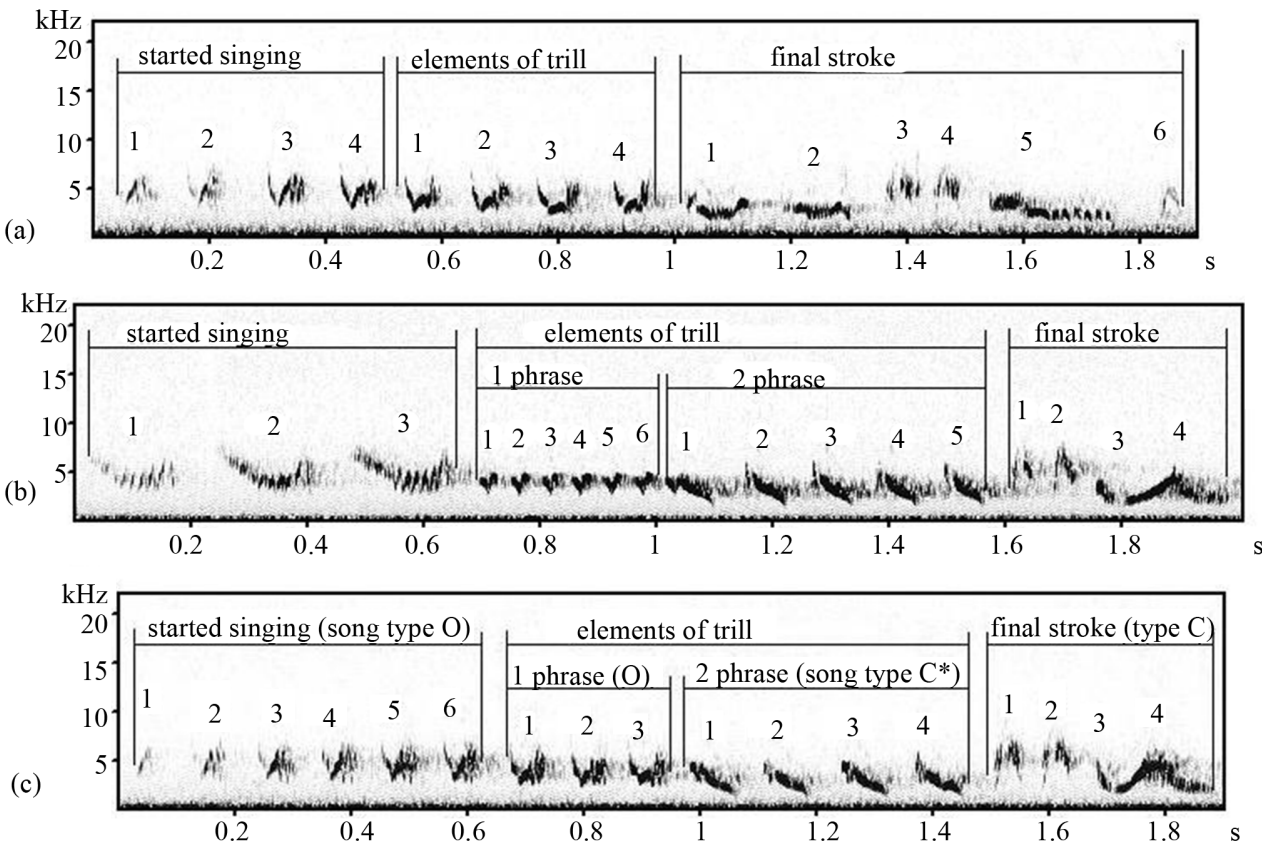

Figure 7. Improvisation in a combination of phrases at singing of one chaffinch male: (a) Song type O, (b) Song type $C^{*}$, (c) Song type OC*.

lopmental interaction) can include cooperating processes of imitation (copying) and improvisation (temporarily-dependent copying, a dispersion young, drift, a regrouping of syllables, phrases).

New song types can be considered as a new growth in a course of "a cultural mutation". Distribution song types in a population corresponds to the assumption, that birds copy them from other individuals of a species at random, and that less than $15 \%$ of these new growths influence creation of new types of songs. One individual of chaffinch male (Fringilla coelebs L.) can have repertoire from 1 - 6 types of songs.

Thus, the examples of lexical distinctions of song types shown by us can be based on mistakes of training (song learning) and processes of improvisation at singing that it is possible to name a cultural mutation in limits of population song cultures. But such cases make small percent from all types of songs of a population.

\subsection{Variability of Elements (Syllables) of Song Types (Phonetic Variability)}

Phonetic (syllabic) variability of types chaffinch songs (Fringilla coelebs L.) consists in distinctions of a manner (ways, styles) performances, pronunciations of syllables, elements of one type-in distinction of their forms on sonograms). We considered change of the form (pronunciation) of elements of one type in different parts of songs: started singing (the row of whistle elements), a trill (an average part) and a final stroke.

Syllabic variability of started singing (the row of whistle elements) it is possible to show by the example of song type C (Figure 2). At all three forms of this song type elements of started singing arc-similar, but sound differently: at song type $C^{*}$ (Figure 2(b)) and $C^{\#}$ (Figure 2(c)) have a little creaking a sound "vji-vji" (it is reflected in more rough form of syllables on sonogram), and at song type C (Figure 2(a)) they sound most precisely, high tone-“fuit-fuit-fuit”, that confirms other pronunciation (phonetic distinction).

Also elements of started singing in song type B (Figure 8(a)) (record on Curonian spit) and the "combined" song type BF (Figure 8(b)) (record in Michurinsk, the Tambov region) are modified in phonetic (have different style of singing, but the similar form on sonogram), therefore were considered dialect. Elements of a trill in difficultly differentiated types of songs D, F, G (Figure 3) are similar in the base, initial form, but nevertheless are performances by different manners, styles at singing.

It is possible to note phonetic variability of a trill in song type C (Figure 2). The second phrase of trill in song type $\mathrm{C}^{*}$ (Figure 2(c)) as against others song forms will consist from "stick-similar" elements. And the first trill phrase of song type $C^{\#}$ (Figure 2(b)) includes wider indistinct syllables. Syllabic variability of a stroke is distinctly visible by the example of song type V (Figure 1) and song type C (Figure 2), that already was partly 
(a)
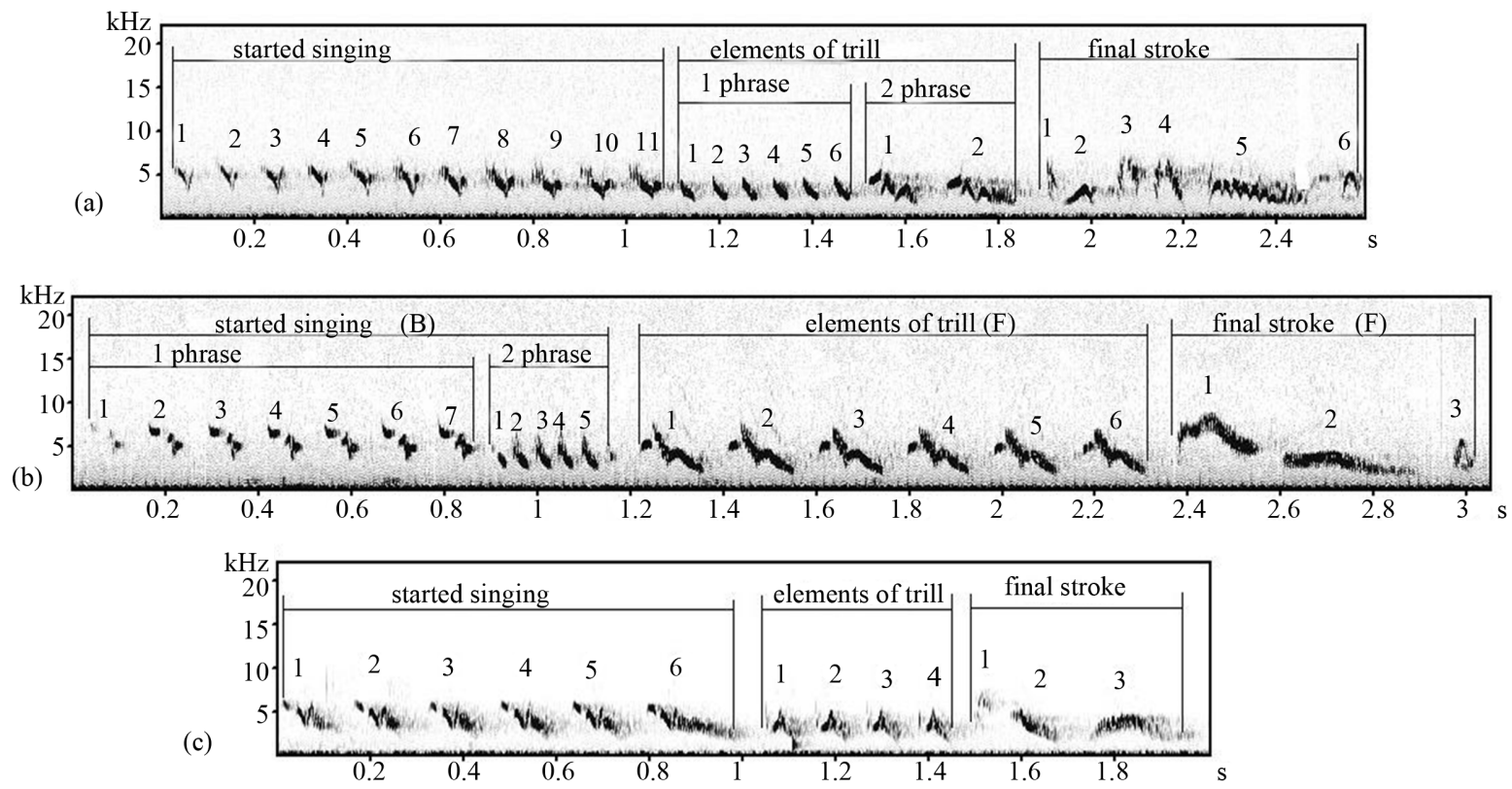

Figure 8. Dialect forms of phrases from types of songs B and F: (a) Song type B (Curonian spit), (b) Song type BF (record in Michurinsk, the Tambov region), (c) Song type F (Curonian spit, the Kaliningrad region).

discussed in section about dialect songs.

The case of variability of a stroke in song type $C^{\#}$ (Figure 2(b)) is especially interesting-last element (which at song type C (Figure 2(a)) the "triangular" form) is separated on three separate subelements. This phonetic difference changes a kind of a phrase as a whole so, and also changes the lexical party (side) of song type. It is sometimes difficult to differentiate new lexical variants from extreme phonetic variants of known syllabic types.

Thus, phonetic variability of syllables (elements) of song types consists, that their base (initial, the basic) structure can be uniform, similar, but modified at singing of different chaffinch males (Fringilla coelebs L.) both within the limits of one local population, and in populations in different territories.

\subsection{Time-and-Frequency Parameters of Local Variants of Song Types}

At comparison of the basic time-and-frequency parameters of local variants of song type C (Table 1) the greatest difference had values of length of songs, the maximal frequency, number of syllables in song types, intervals between songs at singing (these parameters included rather wide range of distribution of the data). In other parameters (the minimal, average (median) frequency, length of trill elements) come to light the most distinguished values (are allocated by a font), but relative uniformity of the data nevertheless is observed.

For chaffinch (Fringilla coelebs L.) selective training (song learning) of species-specific songs in sensitive period is typically. Therefore young birds do not learn songs of other species, and are guided by a time-andfrequency song range of their species. Probably, as a result of such rigid genetic determination species specific songs is observed small variability of the basic time-and-frequency parameters of its different dialect forms (even at the account of a wide variation of values).

Results of the quantitative analysis of dialect forms of phrases of one type (Table 2) are interesting. At comparison of the basic frequency time parameters of the first phrases of song types B and BF (Figure 8(a) and (b)) comes to light a significant difference in their length, the maximal, minimal and average (median) frequency. If to pay attention to the given measurements of a F-similar trill of song type BF (Figure 8(b)), in comparison with dialect it a phrase of started singing in song type F (record on Curonian spit) (Figure 8(c)), come to light similarities in such parameters as the minimal and average (median) frequency, intervals between syllables of a phrase.

Proceeding from the analysis carried out by us, it is possible to draw a conclusion, that the length of dialect phrases and their maximal frequency basically are various, and the minimal frequency and intervals between 
Table 1. The basic time-and-frequency parameters of local variants of chaffinch song type C.

\begin{tabular}{|c|c|c|c|c|c|c|c|c|c|c|c|c|}
\hline \multirow{2}{*}{$\begin{array}{l}\text { Type of } \\
\text { song } \\
\text { (token) }\end{array}$} & \multirow{2}{*}{$\begin{array}{c}\text { Sample } \\
\text { size } \\
\text { (songs) }\end{array}$} & \multirow{2}{*}{$\begin{array}{l}\text { The name } \\
\text { of record } \\
\text { place }\end{array}$} & \multirow{2}{*}{$\begin{array}{l}\text { The } \\
\text { length } \\
\text { of song, } \\
\text { sec }\end{array}$} & \multirow{2}{*}{$\begin{array}{c}\text { Min } \\
\text { frequency, } \\
\text { KHz }\end{array}$} & \multirow{2}{*}{$\begin{array}{c}\text { Max } \\
\text { frequency, } \\
\text { KHz }\end{array}$} & \multirow{2}{*}{$\begin{array}{c}\text { Median } \\
\text { (average) } \\
\text { frequency, } \\
\mathrm{KHz}\end{array}$} & \multirow{2}{*}{$\begin{array}{l}\text { Number of } \\
\text { syllables } \\
\text { in song type }\end{array}$} & \multirow{2}{*}{$\begin{array}{c}\text { Length of } \\
\text { syllables } \\
\text { of start } \\
\text { singing, } \\
\text { sec }\end{array}$} & \multicolumn{2}{|c|}{$\begin{array}{l}\text { Length of } \\
\text { syllables } \\
\text { trill, sec }\end{array}$} & \multirow{2}{*}{$\begin{array}{l}\text { Length of } \\
\text { syllable of } \\
\quad \text { final } \\
\text { stroke, sec }\end{array}$} & \multirow{2}{*}{$\begin{array}{c}\text { Intervals } \\
\text { between } \\
\text { songs, } \\
\text { sec }\end{array}$} \\
\hline & & & & & & & & & $\begin{array}{c}1 \\
\text { phrase }\end{array}$ & $\begin{array}{c}2 \\
\text { phrase }\end{array}$ & & \\
\hline $\mathrm{C}$ & 20 & $\begin{array}{c}\text { Curonian } \\
\text { spit }\end{array}$ & $\begin{array}{c}2.074 \pm \\
0.118\end{array}$ & $\begin{array}{c}1.627 \pm \\
0.131\end{array}$ & $\begin{array}{c}9.698 \pm \\
0.41\end{array}$ & $\begin{array}{c}4.0996 \pm \\
0.173\end{array}$ & $17.25 \pm 0.85$ & $\begin{array}{c}0.1203 \pm \\
0.005\end{array}$ & $\begin{array}{c}0.068 \pm \\
0.003\end{array}$ & $\begin{array}{c}0.1155 \pm \\
0.008\end{array}$ & $=\begin{array}{c}0.071 \pm \\
0.005\end{array}$ & $\begin{array}{c}6.423 \pm \\
1.9\end{array}$ \\
\hline $\mathrm{C}^{\#}$ & 2 & Moscow & $\begin{array}{c}2.73 \pm \\
0.3\end{array}$ & $\begin{array}{c}1.78 \pm \\
0.1\end{array}$ & $\begin{array}{c}8.096 \pm \\
0.6\end{array}$ & $\begin{array}{c}4.54 \pm \\
0.43\end{array}$ & $\begin{array}{l}20 \pm \\
1.73\end{array}$ & $\begin{array}{c}0.22 \pm \\
0.006\end{array}$ & $\begin{array}{c}0.076 \pm \\
0.003\end{array}$ & $\begin{array}{c}0.12 \pm \\
0\end{array}$ & $\begin{array}{c}0.081 \pm \\
0.019\end{array}$ & 8.26 \\
\hline $\mathrm{C}^{*}$ & 3 & $\begin{array}{c}\text { Curonian } \\
\text { spit }\end{array}$ & $\begin{array}{l}2.55 \pm \\
0.082\end{array}$ & $\begin{array}{l}1.3 \pm \\
0.37\end{array}$ & $\begin{array}{c}7.751 \pm \\
0\end{array}$ & $\begin{array}{c}4.478 \pm \\
0\end{array}$ & $\begin{array}{c}19 \pm \\
1.4\end{array}$ & $\begin{array}{c}0.175 \pm \\
0.007\end{array}$ & $\begin{array}{c}0.034 \pm \\
0.01\end{array}$ & $\begin{array}{c}0.084 \pm \\
0.001\end{array}$ & $\begin{array}{c}0.915 \pm \\
0.002\end{array}$ & 22.9 \\
\hline
\end{tabular}

The note: specified are average value and a standard deviation of parameters of song types from statistical calculations for all songs of one type, which were reproduced chaffinch males in the given points of record; the strongest differences counted a difference of parameters $>0.5 \mathrm{KHz}$ in frequency and $>0.02 \mathrm{sec}$ in length (are allocated by a font); ${ }^{*}$ The trill of song type $\mathrm{C}$ will consist of two phrases (Figure 2).

Table 2. The quantitative analysis of dialect phrases of song types B and F.

\begin{tabular}{|c|c|c|c|c|c|c|}
\hline \multirow{3}{*}{$\begin{array}{l}\text { Parameters } \\
\text { of phrase }\end{array}$} & \multicolumn{2}{|c|}{ B (Curonian spit) } & \multicolumn{3}{|c|}{ BF 5 (Michurinsk) } & \multirow{3}{*}{$\begin{array}{c}\mathbf{F} \text { (Curonian spit) } \\
1 \text { phrase (started } \\
\text { singing) }\end{array}$} \\
\hline & \multirow{2}{*}{$\begin{array}{c}1 \text { phrase } \\
\text { (started singing) }\end{array}$} & \multirow{2}{*}{$\begin{array}{l}2 \text { phrase } \\
\text { (trill) }\end{array}$} & \multicolumn{2}{|c|}{$\begin{array}{l}\text { B-similar elements } \\
\text { (started singing) }\end{array}$} & \multirow{2}{*}{$\begin{array}{c}\mathrm{F} \text {-similar } \\
\text { elements (trill) }\end{array}$} & \\
\hline & & & 1 phrase & 2 phrase & & \\
\hline The length of phrase, sec & $1.13 \pm 0.09$ & $0.32 \pm 0.05$ & $0.62 \pm 0.13$ & $0.24 \pm 0.02$ & $1.17 \pm 0.25$ & $1.27 \pm 0.11$ \\
\hline Max frequency, $\mathrm{KHz}$ & $6.57 \pm 0.46$ & $4.626 \pm 0.32$ & $7.3 \pm 0.26$ & $5.9 \pm 0.52$ & $7.44 \pm 0.22$ & $6.25 \pm 0.2$ \\
\hline Min frequency, $\mathrm{KHz}$ & $2.017 \pm 0.13$ & $2.067 \pm 0.1$ & $3.1 \pm 0.3$ & $2.4 \pm 0.12$ & $1.9 \pm 0.17$ & $1.722 \pm 0.14$ \\
\hline Median (average) frequency, $\mathrm{KHz}$ & $4.306 \pm 0.24$ & $3.17 \pm 0.09$ & $5.44 \pm 0.2$ & $3.8 \pm 0.17$ & $4.31 \pm 0.172$ & $4.2 \pm 0.09$ \\
\hline Number of syllables in phrase type & $11.43 \pm 0.79$ & $5.29 \pm 0.76$ & $5.2 \pm 0.8$ & $5 \pm 0$ & $6.4 \pm 1.34$ & $7.6 \pm 0.7$ \\
\hline The length of syllables, sec & $0.058 \pm 0.01$ & $0.037 \pm 0.005$ & $0.08 \pm 0.014$ & $0.04 \pm 0.008$ & $0.15 \pm 0.01$ & $0.12 \pm 0.028$ \\
\hline Intervals between syllables, sec & $0.048 \pm 0.01$ & $0.037 \pm 0.004$ & $0.05 \pm 0.01$ & $0.02 \pm 0.005$ & $0.05 \pm 0.008$ & $0.06 \pm 0.012$ \\
\hline
\end{tabular}

The note: specified are average value and a standard deviation of parameters of dialect phrases from statistical calculations for all songs of one type, which were reproduced chaffinch males in the given points of record; the strongest differences of phrases of one type counted a difference of parameters $>0.5 \mathrm{KHz}$ in frequency and $>0.02 \mathrm{sec}$ in length (are allocated by a font).

syllables appeared in the majority are similar. Values of others time-and-frequency parameters can to vary widely, but within the limits of the certain range.

It is necessary to note, that at the greater distinction of syllables form of dialect phrases on sonograms (up to occurrence of new syllabic patterns), the big distinctions of their basic time-and-frequency parameters are observed (for example, the first phrases in started singing of song types B (Figure 8(a)) and BF (Figure 8(b)).

\section{Conclusions}

Many characteristics of birds singing are precisely depending from social training (song learning) traditions, receiving their vocal patterns by species-specific imitation. Therefore, the tradition and custom should be taken into account in the analysis of geographical variability of vocal behavior of birds [29].

Local populations of birds are formed certain song cultures, which are capable to change during time and to make dialect forms an area of species distribution. Steady dialects of birds in time, the phenomenon of conservatism of the vocal traditions, transmitted to the subsequent generations by means of vocal imitation. For many species, patterns of variability as purchases of vocal traditions are a product of cultural evolution of birds. Cultural evolution is a parameter for species with a historical variety of patterns of microgeographical variability of vocalizations, and also for species of birds with differentiated syllables of songs. But it is not a parameter in morphological variability of birds. 
It is possible to draw a conclusion that as a result of lexical (concerning phrases of songs) and phonetic (concerning syllables, elements of song types) vocal variability, local populations of chaffinch (Fringilla coelebs L.) are formed certain song cultures, which are capable to change during time and to make dialect forms an area of distribution of a species.

For chaffinch (Fringilla coelebs L.), the song has a genetic basis (species-specific features), but by training (song learning) and improvisation, mistakes of copying a variety of song types in a population constantly replenishing [30].

Equally with a substantiation of distinctions and variability of song types of birds as products of mistakes of copying, improvisation at singing and transfers of features song traditions to the following generation during cultural evolution, there is an assumption of gradual phylogeny complication initial "ancient" (more simple on the structure) types of songs in more perfect and complex (difficult) structure song forms existing in a population, on the basis of occurrence of their geographical variability (biomorphism).

The basic time-and-frequency parameters of local variants of chaffinch song types (Fringilla coelebs L.) in the quantitative analysis had insignificant macrogeographical variabilities, and can speak about their importance in transfer and maintenance species specific song traditions. The most stable parameters of local variants of songs of one type appeared minimal and average (median) frequency, values of length and intervals of trill elements.

Proceeding from samples, made by us in different regions of the European Russia (northwest and the central part), it is possible to draw a conclusion, that some song types of chaffinch (Fringilla coelebs L.) exist subdialects (insignificant phonetic distinctions of syllables). For example, song types B, M, D, G, V, S, U, and dialects (different phonetic norms of types of songs), $\mathrm{C}, \mathrm{C}^{*}$ and $\mathrm{C}^{\#}, \mathrm{~F}, \mathrm{I}, \mathrm{J}, \mathrm{N}$, and there are also stable types of song (samples of different regions are invariable)—song type A.

Vocal norms (installations), likely, can be judged by quantity (amount) of individuals in a population, who adheres those or others song cultures (ways of singing) of different types of songs. If the majority of males sings any song type by such style (a manner of performance), then it will be the vocal norm (installation) on this song type (or on type of a phrase) in the given population. But it is difficult to define vocal norms of a population at repertoires of great volume (when types of songs much).

Full dialect of chaffinch song (Fringilla coelebs L.) in the certain territory would be more correct to count the presence of dialect forms on all song types in a population known by us (originally 22 types have been found), and that, likely, it is almost impossible, because of sample limitation and constant mixing of vocal traditions of different populations as a result of migrations.

\section{References}

[1] Marler, P. (1952) Variation in the Song of the Chaffinch Fringilla coelebs. Ibis, 98, 458-472.

[2] Marler, P. and Tamura, M. (1962) Song Dialects in Three Populations of White-Crowned Sparrows. Condor, 64, 368377. http://dx.doi.org/10.2307/1365545

[3] Sick, H. (1939) Ueber die Dialektbildung beirn Regenruf des Buchfinken. Journal of Ornit, 87, 568-592. http://dx.doi.org/10.1007/BF01950720

[4] Poulsen, H. (1951) Inheritance and Leaning in the Song of the Chaffinch (Fringilla coelebs). Behaviour, 3, $216-228$. http://dx.doi.org/10.1163/156853951X00278

[5] Kurath, H. (1972) Studies in Areal Linguistics. Indiana University Press, Bloomington, 130.

[6] Lemon, L.E. (1975) How Birds Develop Song Dialects. Condor, 77, 385-406. http://dx.doi.org/10.2307/1366087

[7] Slater, P.J.B. and Ince, S.A. (1979) Cultural Evolution in Chaffinch Song. Behaviour, 7, 146-166. http://dx.doi.org/10.1163/156853979X00142

[8] Mundinger, P.C. (1980) Animal Cultures and a General Theory of Cultural Evolution. Ethology and Sociobiology, 1, 183-223. http://dx.doi.org/10.1016/0162-3095(80)90008-4

[9] Mundinger, P.C. (1979) Call Learning in the Carduelinae: Ethological and Systematic Considerations. Systematic Zoology, 28, 270-283. http://dx.doi.org/10.2307/2412582

[10] Thielcke, G. (1965) Gesangsgeographische Variation des Gartenbaumläufers (Certhia brachydactyla) im Hinblick auf das Artbildungsproblem. Zeitschrift fur Tiërpsychologie, 22, 542-566. http://dx.doi.org/10.1111/j.1439-0310.1965.tb01506.x

[11] Thielcke, G. (1969) Geographic Variation in Bird Vocalizations. Cambridge University Press, London, 311-340. 
[12] Kreutzer, M. (1974) Stereotypie et varianttions dans les chants de proclamation territoriale chez le Troglodyte (Troglodytes troglodytes). Reviewer Compared Animals, 8, 270-286.

[13] Kroodsma, D.E. (1974) Song Learning, Dialects, and Dispersal in the Bewick’s Wren. Tierpsychology, 35, 352-380.

[14] Thorpe, W.H. (1958) The Leaning of Song Patterns by Birds, with Especial Reference to the Song Chaffinch Fringilla coelebs. Ibis, 100, 535-570. http://dx.doi.org/10.1111/j.1474-919X.1958.tb07960.x

[15] Marler, P. (1956) The Voice of the Chaffinch and Its Function as a Language. Ibis, 98, 231-261. http://dx.doi.org/10.1111/j.1474-919X.1956.tb03042.x

[16] Nottebohm, F. (1967) The Role of Sensory Feedback in Development of Avian Vocalizations. Proceedings of the 14th International Ornithology Congress, Blackwell Science Publishers, Oxford-Edinburg, 265-280.

[17] Promptov, A.N. (1930) Geographical Variability of Chaffinch Song in Connection with the Common Questions of Seasonal Flights of Birds. Zoology Journal, 10, 17-40.

[18] Thielcke, G. (1961) Stammesgeschichte und geographische Variation des Gesanges unserer Baumläufer. Verhandlungen der Ornithologischen Gesellschaft in Bayern, 14, 39-74.

[19] Slater, P.J.B., Clement, F.A. and Goodfellow, D.J. (1984) Local and Regional Variations in Chaffinch Song and the Question of Dialects. Behaviour, 88, 76-97. http://dx.doi.org/10.1163/156853984X00498

[20] Nottebohm, F. (1969) The Song of the Chingolo, Zonotrichia capensis, in Argentina: Description and Evaluation of a System of Dialects. Condor, 71, 299-315. http://dx.doi.org/10.2307/1366306

[21] Slater, P.J.B. (1981) Chaffinch Song Repertoires: Observations, Experiments and a Discussion of Their Significance. Zeitschrift fur Tiërpsychologie, 72, 177-184.

[22] Mundinger, P.C. (1982) Microgeographic and Macrogeographic Variation in Acquired Vocalizations of Birds. Academic Press, New York, 147-208.

[23] Baker, M.C. (1975) Song Dialects and Genetic Differences in White-Crowned Sparrows (Zonotrichia leucophrys). Evolution, 29, 226-241. http://dx.doi.org/10.2307/2407210

[24] Baptista, L.F. (1975) Song Dialects and Demes in Sedentary Populations of the White-Crowned Sparrow (Zonotrihcia leucophrys nuttalli). University of California Publications in Zoology, Berkeley, 1-52.

[25] Payne, R.B. (1981) Population Structure and Social Behavior: Models for Testing Ecological Significance of Song Dialects in Birds. In: Alexander, R.D. and Tinkle, D.W., Eds., Natural Selection and Social Behavior: Recent Research and New Theory, Chiron, New York, 108-119.

[26] Slater, P.J., Ince, S.A. and Colgan, P.W. (1980) Chaffinch Song Types: Their Frequencies in the Population and Distribution between Repertoires of Different Individuals. Behaviour, 75, 207-218. http://dx.doi.org/10.1163/156853980X00401

[27] Espmark, Y.O., Lampe, H.M. and Bjerke, T.K. (1989) Song Conformity and Continuity in Song Dialects of Redwings Turdus iliacus and Some Ecological Correlates. Ornis Scandinavica, 20, 1-12. http://dx.doi.org/10.2307/3676701

[28] Jellis, R. (1977) Bird Sounds and Their Meaning. British Broadcasting Corporation, Cambridge, 256.

[29] Kroodsma, D.E., Miller, E.H. and Quellet, H. (1982) Communication and Behavior an Interdisciplinary Series. In: Kroodsma, D.E. and Miller, E.H., Eds., Vol. 2: Song Leaning and Its Consequence, Academic Press, London, 347.

[30] Ince, S.A., Slater, P.J.B. and Weismann, C. (1980) Changes with Time in the Song of a Populations Chaffinches. Condor, 82, 285-290. http://dx.doi.org/10.2307/1367393 